\title{
Oncologic surgical resection with intravascular covered stent placement in patients with carotid artery encased by metastatic cancer-Our experience with 5 patients
}

\author{
Kai Liu ${ }^{1}$, Haidong Zhang², Huanyu Jiang', Shanchun Gong², Xianjun Lyu², and Zhenkun \\ $\mathrm{Yu}^{1}$ \\ ${ }^{1}$ Southeast University \\ ${ }^{2}$ The Affiliated BenQ Hospital of Nanjing Medical University
}

April 15, 2021

\begin{abstract}
Importance: Tumor encasement of the common carotid artery (CCA) and/or the internal carotid artery (ICA) in patients with advanced head and neck tumors represents a significant surgical challenge. At present, there are few reports on the treatment approach that can achieve the maximal oncological resection and reduce the difficulty of operation without affecting the carotid artery blood flow. Objective: To examine whether the combination of oncologic complete tumor resection and intravascular covered stent placement is more advantageous in the management of advanced head and neck cancer. Design, Setting, and Participants: Five patients with advanced head and neck squamous cell carcinoma (AHNSCC) invading one side of the carotid artery were retrospectively enrolled. The contrast-enhanced computed Tomography (CT) and angiography were performed to assess the severity of extrinsic tumor compression to the carotid artery. Covered stent was placed intra-arterially at least 1 $\mathrm{cm}$ proximal and distal beyond the area of tumor involvement. The tumor and the involved carotid artery were resected, and pectoralis major flap transfer was utilized for coverage of the great vessels supported with intra-arterial covered stent. Main Outcomes and Measures: Efficacy of oncologic complete tumor resection combined with endovascular stent placement. Results: The post-stenting demonstrated an improvement in the appearance and caliber of the affected carotid artery. Four patients experienced transient bradycardia and hypotension. All five patients underwent R0 resection. Postoperatively, the flap all had rich vascularity and healing. Three patients underwent adjuvant radiotherapy or chemoradiation. With median follow-up 6.5 months, one patient died of multiple organ failures at 6.5 months after surgery; one patient developed tracheal stoma recurrence and treated with salvaged surgery; the three other patients had no disease recurrence in their last follow-ups. Conclusions and Relevance: Surgical resection with intravascular covered stent placement could potentially achieve the maximal oncological resection without compromise carotid artery blood flow in patients with carotid artery encased head and neck cancer.
\end{abstract}

Oncologic surgical resection with intravascular covered stent placement in patients with carotid artery encased by metastatic cancer-Our experience with 5 patients

\section{Key Points:}

* This approach could potentially achieve the maximal oncological resection without compromise of carotid artery blood flow.

*This approach reduces the incidence of potential risk of cerebrovascular complications.

* This approach may be more beneficial in cases with less optimal condition for vascular reconstruction, or the potential of $\mathrm{R} 0$ tumor resection. 
* This approach could still be used to complete tumor resection without the possibility of major blow-out risk in some cases of recurrence after radiotherapy.

* The pedicled pectoralis major musculocutaneous flap was used to repair the defect, which not only protected the exposed carotid artery, but also provided rich vascularity.

\section{1、INTRODUCTION}

Tumor encasement of the common carotid artery (CCA) and/or the internal carotid artery (ICA) in patients with advanced head and neck tumors represents a significant surgical challenge. The 5-year survival rate is about $5 \%-13 \%^{1}$ partly due to risks of stroke or carotid blowout syndrome (CBS).Previous approaches to the prevention of CBS (e.g., surgical ligation, endovascular embolization, covered stent implantation) were palliative and most reports did not further solve the tumor burden ${ }^{2-4}$.Simple surgical management, e.g., peeling the tumor off the carotid wall, resection with ligation of the carotid artery, resection with or without revascularization, results in non $\mathrm{R} 0$ resection or intraoperative and postoperative complications, even the difficulty of the operation is a significant challenge for the surgeon ${ }^{1,5-6}$. Therefore, we report our experience with combination of oncologic complete tumor resection and intravascular covered stent placement in patients with advanced head neck cancer.

\section{2、MATERIALS AND METHODS}

This study was approved by the institutional review board of ***. Between July 2019 and January 2020, five patients with advanced head and neck squamous cell carcinoma (AHNSCC) invading one side of the carotid artery, underwent intra-arterial covered stent placement of the CCA/ICA prior tumor resection at ***.

The preoperative angiography (Figure 1A ) were performed to assess the severity of extrinsic tumor compression to the carotid artery. Covered stent (GORE VIABAHN, W.L.Gore\& Associates, lnc. USA) was placed intra-arterially at least $1 \mathrm{~cm}$ proximal and distal beyond the area of tumor involvement. Each patient was administered low molecular weight heparin (LMWH) 5000IU daily for 6-10 days. Oncologic tumor resection was performed 2 to 3 days after stent placement. The tumor and the involved carotid artery were resected en bloc, and pectoralis major flap transfer was utilized for coverage of the great vessels supported with intra-arterial covered stent.

\section{3、RESULTS}

All five patients' characteristics and previous treatments were demonstrated on Table 1 and Table 2 . The post-stenting angiography (Figure 1B ) demonstrated an improvement in the appearance and caliber of the affected carotid artery. The carotid wall could be dissected from the stent without difficulty and en blocresection of the surrounding tumor with attempted R0 resection.Figure $\mathbf{2 A}$ and $\mathbf{2 B}$ demonstrated appearance of the covered stent in carotid artery. The mean age was 52.2 years (range, 41-60 years), and the median follow-up was 6.5 months (range, 4-9 months). After placement of the covered stent prior to surgical resections, four patients experienced transient bradycardia (30-40 beats/min)and hypotension (50/30-70/50 $\mathrm{mmHg}$ ).No stroke occurred in these five patients. Intraoperatively, we noted that in two patients' the whole carotid artery wall was involved, in two patients' tumor invaded only the tunica adventitia of the carotid artery, and one other patient's tumor did not directly invade the carotid artery, there was only extrinsic compression. All five patients underwent R0 resection (no positive margins of the resection line of the specimen) and there were no intraoperative complications. The type of tumor in all patients was squamous cell carcinoma. Postoperatively, all patients healed because of rich vascularity of the flap, and no infection or necrosis occurred. Three patients underwent adjuvant radiotherapy or chemoradiation. With median follow-up 6.5 months, one patient died of multiple organ failures at 6.5 months after surgery; one patient developed tracheal stoma recurrence and was treated with salvage surgery; the three other patients had no disease recurrence at their last follow-up. We have not observed any postoperative spontaneous carotid artery rupture, stroke, or late graft occlusion.

\section{4、DISCUSSION}


Management of the carotid artery encased by tumor is an intraoperative challenge. Surgeons are very cautious in dissecting the tumor from the carotid artery when there is only extrinsic compression. Removal of the tumor in that setting with release of extrinsic compression reestablished blood flow to the brain. Although resection and ligation of the carotid artery is a classic option, there is a $17 \%$ to $79 \%$ risk of stroke ${ }^{1,7}$. Unlike ligation after carotid artery resection, the placement of a covered stent retains the normal carotid blood flow during surgery, and reduces the incidence of potential risk of cerebrovascular complications. Several previous reports suggested that en bloc resection of the tumor together with invaded segment of carotid artery followed by vascular reconstruction is an excellent option in management of advanced head and neck cancer $^{5,7-8}$. However, in cases where the ICA close to the skull base is involved a reconstruction without special techniques like mandibulotomies may be difficult ${ }^{9}$. Comparing to immediate reconstruction following carotid artery resection, the covered stent may be more beneficial in cases with less optimal condition for vascular reconstruction, or the potential of R0 tumor resection. In difference to the cases reported by Markiewicz et al., which only invaded resection of the adventitia ${ }^{6}$, two of the cases reported by us invaded full thickness of the wall of carotid artery. The stent was placed intravascularly in the involved carotid artery, extended and passed beyond the site of tumor involvement, allowing the surgeon to completely resect the tumor along with involved vessel wall. It is well known that in some cases of recurrent advanced head and neck cancer, the tumor does not actually penetrate the artery wall, but is in the middle of the post-radiation scar tissue, and therefore cannot be resected without major blow-out risk. The tumor resection could still be complete with this approach.

The resection of recurrent advanced head and neck cancer is usually performed in a wide range and is prone to expose the airway or oropharyngeal mucosa. In addition, some patients have cervical tissue fibrosis caused by radiotherapy, leading to insufficient vascularity to local skin and muscle, which increases the possibility of postoperative infection and delayed wound healing ${ }^{10}$. Therefore, in this study, the pedicled pectoralis major musculocutaneous flap was used to repair the defect, which not only protected the exposed carotid artery, but also provided rich vascularity. Postoperative infection and delayed wound healing were not seen in any of our patients.

This approach could potentially achieve the maximal oncological resection without compromise of carotid artery blood flow. Although our limited experience with these five cases has demonstrated effective management using covered stent placement in patients with carotid artery encased by advanced head and neck cancer, long-term follow-up with a large number of patients is required to determine whether the carotid stent placement is superior to carotid artery ligation, resection and reconstruction, because of its potential benefit of minimizing intracranial vascular complications.

\section{REFERENCES}

1. Nishinari K, Krutman M, Valentim LA, et al. Late surgical outcomes of carotid resection and saphenous vein graft revascularization in patients with advanced head and neck squamous cell carcinoma. Annals of vascular surgery. 2014;28(8):1878-1884.

2. Wong DJY, Donaldson C, Lai LT, et al. Safety and effectiveness of endovascular embolization or stentgraft reconstruction for treatment of acute carotid blowout syndrome in patients with head and neck cancer: Case series and systematic review of observational studies. Head \& neck. 2018;40(4):846-854.

3. Durmaz H, Ergun O, Birgi E, Bayir O, Saylam G. Endovascular management of the carotid blowout syndrome: a single-center experience.European archives of oto-rhino-laryngology : official journal of the European Federation of Oto-Rhino-Laryngological Societies (EUFOS) : affiliated with the German Society for Oto-Rhino-Laryngology - Head and Neck Surgery. 2019;276(10):2881-2886.

4. Manzoor NF, Rezaee RP, Ray A, et al. Contemporary management of carotid blowout syndrome utilizing endovascular techniques. The Laryngoscope. 2017;127(2):383-390.

5. Bäck LJJ, Aro K, Tapiovaara L, et al. Sacrifice and extracranial reconstruction of the common or internal carotid artery in advanced head and neck carcinoma: Review and meta-analysis. Head $\mathcal{E}$ 
neck.2018;40(6):1305-1320.

6. Markiewicz MR, Pirgousis P, Bryant C, et al. Preoperative Protective Endovascular Covered Stent Placement Followed by Surgery for Management of the Cervical Common and Internal Carotid Arteries with Tumor Encasement. Journal of neurological surgery Part B, Skull base.2017;78(1):52-58.

7. Illuminati G, Schneider F, Minni A, Calio FG, Pizzardi G, Ricco JB. Resection of recurrent neck cancer with carotid artery replacement.Journal of vascular surgery. 2016;63(5):1272-1278.

8. Chung EJ, Kwon KH, Yoon DY, Cho SW, Kim EJ, Rho YS. Clinical outcome analysis of 47 patients with advanced head and neck cancer with preoperative suspicion of carotid artery invasion. Head $\&$ neck.2016;38 Suppl 1:E287-292.

9. Vikatmaa P, Mäkitie AA, Railo M, Törnwall J, Albäck A, Lepäntalo M. Midline mandibulotomy and interposition grafting for lesions involving the internal carotid artery below the skull base. Journal of vascular surgery. 2009;49(1):86-92.

10. He XB, Li JJ, Chen YH, Shu C, Tang QL, Yang XM. Treatment of recurrent head and neck carcinoma involving the carotid artery: carotid reconstruction with ePTFE graft. European archives of oto-rhinolaryngology : official journal of the European Federation of Oto-Rhino-Laryngological Societies (EUFOS) : affiliated with the German Society for Oto-Rhino-Laryngology - Head and Neck Surgery.2011;268(12):18171822 .

Table

Table 1. Patient details

\begin{tabular}{|c|c|c|c|c|c|}
\hline Patient & 1 & 2 & 3 & 4 & 5 \\
\hline Age (yeas) & 54 & 48 & 41 & 58 & 60 \\
\hline Sex & Male & Male & Male & Male & Male \\
\hline Primary site & Larynx & Tongue & Larynx & Larynx & Nasopharynx \\
\hline $\begin{array}{l}\text { TNM } \\
\text { classification }\end{array}$ & T4bN2bM0 & T4bN2bM0 & T4bN2bM0 & T4bN2cM0 & T4bN2aM0 \\
\hline $\begin{array}{l}\text { Previous } \\
\text { treatment }\end{array}$ & Surgery & Surgery & Surgery & $\begin{array}{l}\text { Surgery + RT } \\
+\mathrm{CT}\end{array}$ & $\mathrm{RT}$ \\
\hline $\begin{array}{l}\text { Vascular } \\
\text { intervention }\end{array}$ & $\begin{array}{l}\text { Right CCA } \\
\text { stenting }\end{array}$ & $\begin{array}{l}\text { Right } \\
\text { CCA/ICA } \\
\text { stenting }\end{array}$ & $\begin{array}{l}\text { Right CCA } \\
\text { stenting }\end{array}$ & $\begin{array}{l}\text { Right CCA } \\
\text { stenting }\end{array}$ & $\begin{array}{l}\text { Right } \\
\text { CCA/ICA } \\
\text { stenting }\end{array}$ \\
\hline $\begin{array}{l}\text { Surgical } \\
\text { Treatment }\end{array}$ & $\begin{array}{l}\text { Radical neck } \\
\text { dissection + } \\
\text { Myofascial } \\
\text { pectoralis } \\
\text { major flap }\end{array}$ & $\begin{array}{l}\text { Radical neck } \\
\text { dissection }+ \\
\text { Myofascial } \\
\text { pectoralis } \\
\text { major flap }\end{array}$ & $\begin{array}{l}\text { Radical neck } \\
\text { dissection + } \\
\text { Myofascial } \\
\text { pectoralis } \\
\text { major flap }\end{array}$ & $\begin{array}{l}\text { Radical neck } \\
\text { dissection + } \\
\text { Myofascial } \\
\text { pectoralis } \\
\text { major flap }\end{array}$ & $\begin{array}{l}\text { Radical neck } \\
\text { dissection }+ \\
\text { Myofascial } \\
\text { pectoralis } \\
\text { major flap }\end{array}$ \\
\hline \multicolumn{2}{|c|}{ Resectclassificatidß0 } & Ro & $\mathrm{R} 0$ & R0 & Ro \\
\hline Complications & $\begin{array}{l}\text { Transient } \\
\text { bradycar- } \\
\text { diaand } \\
\text { hypotension }\end{array}$ & $\begin{array}{l}\text { Transient } \\
\text { bradycar- } \\
\text { diaand } \\
\text { hypotension }\end{array}$ & $\begin{array}{l}\text { Transient } \\
\text { bradycar- } \\
\text { diaand } \\
\text { hypotension }\end{array}$ & $\begin{array}{l}\text { Transient } \\
\text { bradycar- } \\
\text { diaand } \\
\text { hypotension }\end{array}$ & None \\
\hline $\begin{array}{l}\text { Pathological } \\
\text { type }\end{array}$ & $\begin{array}{l}\text { Squamous cell } \\
\text { carcinoma }\end{array}$ & $\begin{array}{l}\text { Squamous cell } \\
\text { carcinoma }\end{array}$ & $\begin{array}{l}\text { Squamouscell } \\
\text { carcinoma }\end{array}$ & $\begin{array}{l}\text { Squamous cell } \\
\text { carcinoma }\end{array}$ & $\begin{array}{l}\text { Squamous cell } \\
\text { carcinoma }\end{array}$ \\
\hline $\begin{array}{l}\text { Postoperative } \\
\text { treatment }\end{array}$ & None & $\begin{array}{l}\mathrm{CT}(\mathrm{DDP} \\
100 \mathrm{mg} / \mathrm{m}^{2}+ \\
5-\mathrm{FU} 1000 \\
\left.\mathrm{mg} / \mathrm{m}^{2}\right)\end{array}$ & $\begin{array}{l}\text { RT (total dose of } \\
70 \mathrm{~Gy} \text { ) }\end{array}$ & $\begin{array}{l}\mathrm{RT}+\mathrm{CT} \text { (total } \\
\text { dose of } 70 \mathrm{~Gy}+ \\
\mathrm{DDP} 20 \mathrm{mg} / \mathrm{m}^{2} \\
+5-\mathrm{FU} 200 \\
\left.\mathrm{mg} / \mathrm{m}^{2}\right)\end{array}$ & None \\
\hline
\end{tabular}




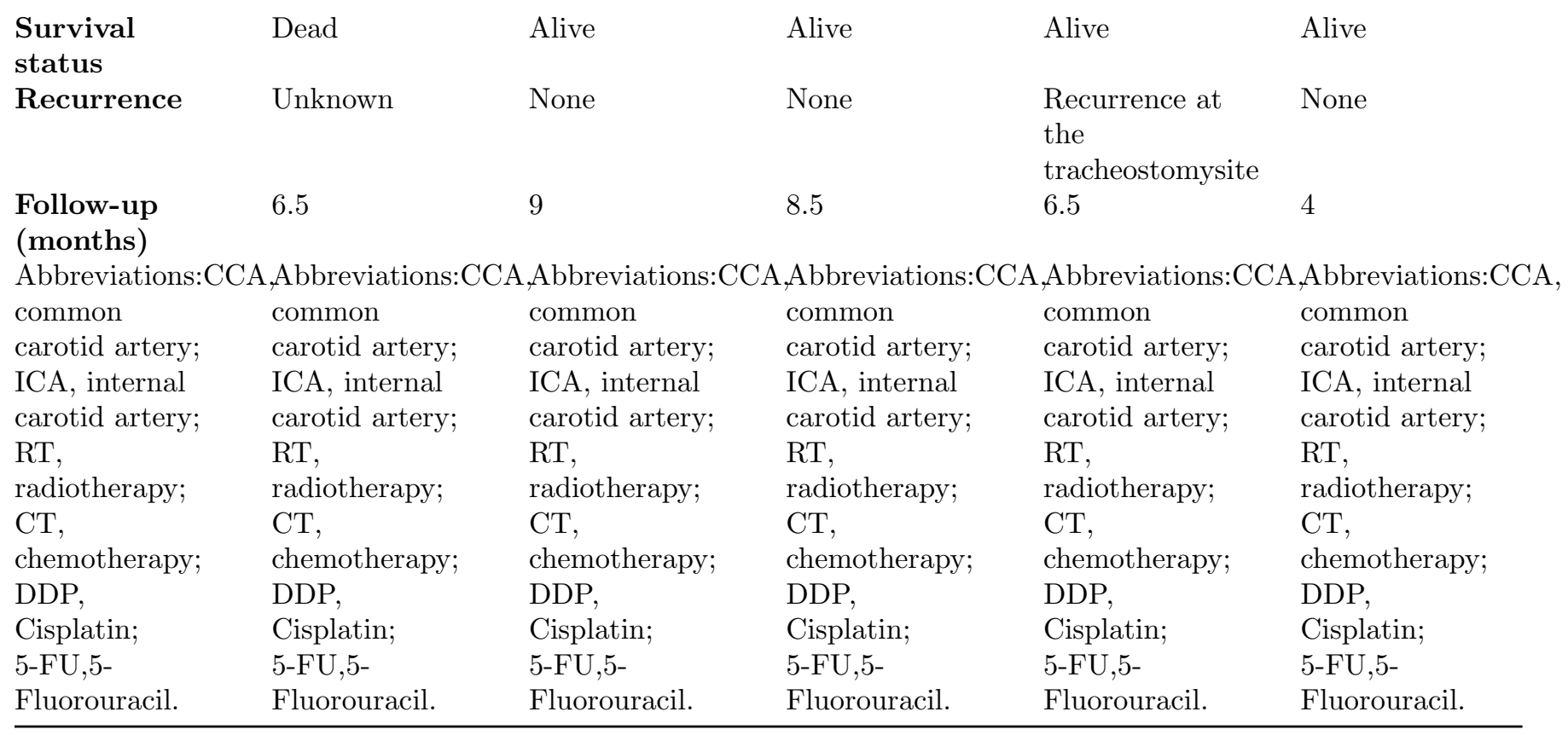

Table 2. Clinical characteristics of patients

\begin{tabular}{lr}
\hline Variable & Patien \\
Age, mean (range),y & $52.2(41$ \\
Follow-up, median (range), m & $6.5(4-9$ \\
Sex & \\
Male & $5(100.0)$ \\
Female & $0(0.0)$ \\
Primary site & $3(60.0)$ \\
Tarynx & $1(20.0)$ \\
Nasopharynx & $1(20.0)$ \\
Clinical stage & $0(0.0)$ \\
I & $0(0.0)$ \\
II & $0(0.0)$ \\
II & $5(100.0$ \\
Previous treatment & $3(60.0)$ \\
Surgery & $1(20.0)$ \\
Surgery + RT + CT & $1(20.0)$ \\
RT & \\
Right CCA stenting & $3(60.0)$ \\
Right CCA/ICA stenting & $2(40.0)$ \\
Surgical Treatment & $5(100.0$ \\
Resectclassification & $5(100.0$ \\
R1 & $0(0.0)$ \\
R2 & $0(0.0)$ \\
Complications &
\end{tabular}


Transient bradycardia and hypotension

None

$1(20.0)$

Postoperative treatment

CT

$1(20.0)$

RT

$1(20.0)$

$\mathrm{RT}+\mathrm{CT}$

$1(20.0)$

None

$2(40.0)$

Survival status

Alive

$1(20.0)$

Recurrence

Abbreviations: CCA, common carotid artery; ICA, internal carotid artery; RT, radiotherapy; CT, chemotherapy.

Abbrevi

Figure legends:

Figure 1. An angiogram of the carotid

A, The red square depicts a significant compression and narrowing of CCA; B, The red square depicts the restored form of the CCA through placement of the covered stent.

Figure 2. The process of en bloc resection of the cancer mass

A, CCA encasement underwent preoperative covered stent placement; B, The covered stent with obvious thread in the CCA. CCA, common carotid artery.
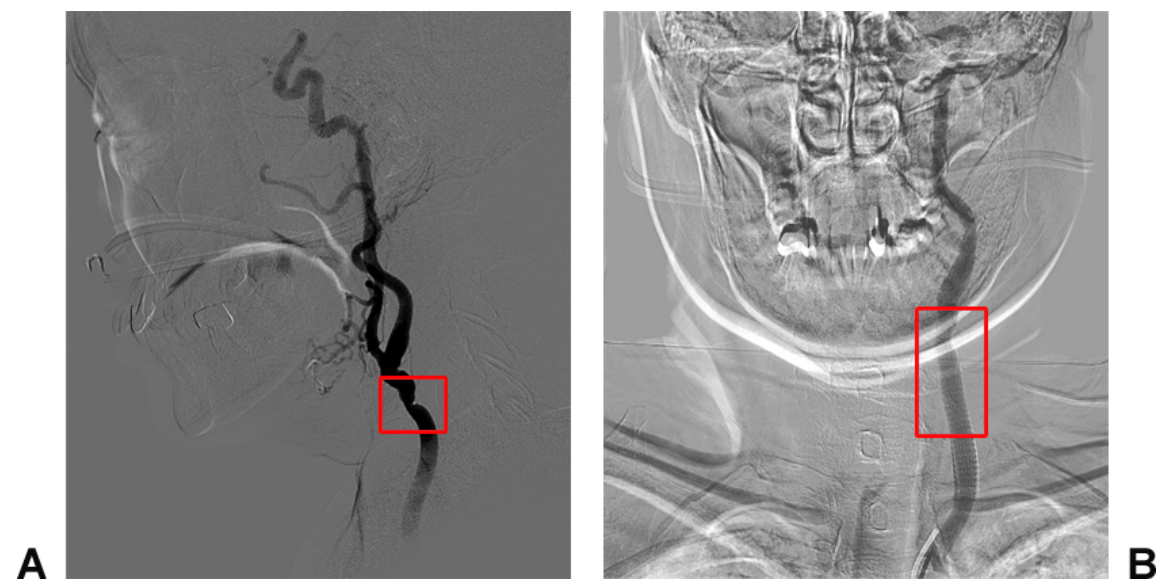

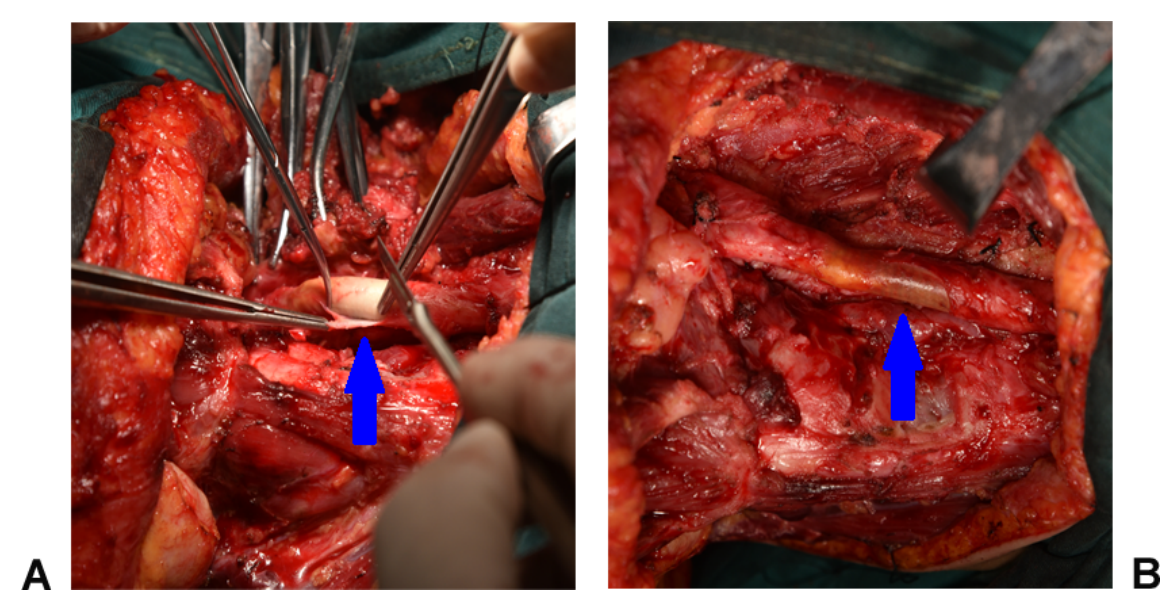

\section{Hosted file}

Table 1.pdf available at https://authorea.com/users/407922/articles/518098-oncologicsurgical-resection-with-intravascular-covered-stent-placement-in-patients-with-carotidartery-encased-by-metastatic-cancer-our-experience-with-5-patients

\section{Hosted file}

Table 2.pdf available at https://authorea.com/users/407922/articles/518098-oncologicsurgical-resection-with-intravascular-covered-stent-placement-in-patients-with-carotidartery-encased-by-metastatic-cancer-our-experience-with-5-patients 